\title{
EKSPERIMEN PEMBENTUKAN KERAK GIPSUM PADA PIPA BERALIRAN LAMINIR DENGAN PARAMETER LAJU ALIR DAN ADITIF ION $\mathrm{C}_{\mathrm{U}}{ }^{2+}:$ KAJIAN KINETIS
}

\author{
Wiji Mangestiyono $^{1)}$, A.P. Bayuseno ${ }^{2)}$, Stefanus Muryanto ${ }^{3)}$ \\ ${ }^{1)}$ Program Studi Diploma III Teknik Mesin Fakultas Teknik Undip \\ ${ }^{2)}$ Teknik Mesin Fakultas Teknik Undip \\ ${ }^{3)}$ Fakultas Teknik Untag
}

\begin{abstract}
Wiji Mangestiyono, , A.P. Bayuseno ${ }^{2}$, Stefanus Muryanto, in this paper explain that the problem of gypsum scaling becomes a trouble for some industry in which use some water for its system. Some disadvanteges come up because of : the time of industrial process will be more longer and production cost increase necesery. To prevent the growth of scale, the experiment must be done. Researcher try to answer this problem so an experimental about kinetic study of gypsum scaling established. Flowrate would be a parameter with assume that it has effect on reaction flow. The result of this experiment are : reaction rate increase when flow rate increase; adition some aditives becomes reaction rate decrease.
\end{abstract}

Keywords : crystal, flow rate, reactio rate, gipsum

\section{PENDAHULUAN}

Setiap industri yang menggunakan air dalam sistem kerjanya bisa dipastikan bahwa selalu mempunyai permasalahan dengan pengerakan. Pengerakaan terjadi pada komponen industri yang sangat komplek, misalnya pada industri listrik tenaga uap, pengerakan terjadi hampir pada seluruh komponen yang ada pada industri tersebut meliputi komponen : Water Reservoir, Boiler, Heat Exchanger, Condenser (Jamaialahmadi,2007).

Pengerakan merupakan proses alami yang terjadi karena adanya reaksi antara kandungan kandungan yang tidak dikendaki yang terdapat pada air. Kandungan yang dimaksudkan bisa meliputi (Popescu,2008) : alkalin, kalsium, klorid, Sulfat, Nitrat, Besi, Seng, Tembaga, Phosphat, Aluminium dll.

Selain faktor kimia yang mempengaruhi proses pengerakan ada pula faktor lain yaitu fisik (Managing Queensland Natural Resources, 2006), misalnya temperatur, laju alir dan model aliran. Untuk kondisi lingkungan temperatur proses tidak mempunyai variasi yang besar yaitu masih berkisar pada suhu kamar sebagai contoh pada industri air minum. Untuk beberapa industri temperatur proses sangat variatif sesuai dengan kebutuhan industri itu sendiri dimana akan memberikan pengaruh terhadap proses pengerakan.

Faktor fisik yang lainnya adalah model aliran yaitu apakah aliran yang ada pada proses pengerakan adalah laminer atau turbulen dimana keduanya memberikan pengaruh yang berbeda pada proses pengerakan. Pengerakan yang terjadi secara assimtotik mempunyai perilaku yang berbeda dalam arah radial mau pun arah aksial (McKeon dkk,2007). Kecepatan aliran adalah faktor fisik yang mempunyai pengaruh kuat terhadap proses pengerakan. Ia memberikan tekanan aksial maupun radial yang berpengaruh terhadap proses pembentukan inti kerak. Kecepatan aliran mempunyai hubungan yang negatif terhadap waktu kristalisasi tetapi positif terhadap jumlah impuritas yang ada dalam air. Semakin tinggi kecepatan akan semakin rendah waktu reaksi pembentukan inti, akan tetapi jumlah deposit yang diangkut menjadi semakin banyak.

Kerak yang terjadi pada dinding pipa atau pada bejana akan berakibat menimbulkan berbagai kerugian pada system industri. Kerugian kerugian yang terjadi bisa dijabarkan dalam poinpoin berikut : Intensitas kerak ; menyebabkan berkurangnya penampang pipa atau bejana dimana fluida dialirkan. Hal ini mengakibatkan menurunnya debit aliran sehingga proses industri akan menjadi lebih lama serta beaya produksi akan lebih mahal.

Penambahan ketebalan dinding ; misalnya dinding ketel pipa air dimana pada pipa tsb dilakukan pembakaran maka proses perpindahan panas secara konduksi akan terhalang oleh lapisan kerak yang berakibat terjadinya penurunan efisiensi perpindahan panas. Permasalahan ini tentu saja akan menjadikan pemborosan yang kontradiktif dengan isu hemat enerji.

Bila dilakukan pembersihan pada kerak yang menempel pada dinding dimana kerak menempel maka sistem produksi harus dihentikan sementara dimana akan mempunyai imbas berkurangnya produksi dan meningkatnya anggaran pembayaran buruh industri.

Dari uraian yang telah disebutkan ternyata impuritas yang sangat berpeluang menimbulkan kerak adalah kalsium dan sulfat dimana keduanya bersenyawa membentuk endapan $\mathrm{CaSO}_{4}$ yang dikenal sebagai kerak gipsum. Kerak gipsum sangat merugikan dalam proses produksi oleh karenanya harus dilakukan usaha untuk menghambat pembentukannya dengan cara mengatur parameter proses pertumbuhannya dimana salah satu 
parameternya adalah laju alir. Selain itu langkah untuk menghambat pertumbuhan kerak gipsum dilakukan pula dengan menggunakan aditif yang bertujuan untuk menghambat pertumbuhan kristal kerak gipsum.

Dalam penelitian ini peneliti membatasi permasalahan kerak yang dikaji yaitu kerak yang timbul dari reaksi kalsium dengan sulfat yang lazim disebut dengan istilah kerak gipsum. Pemilihan ini didasari pertimbangan bahwa kerak gipsum adalah jenis kerak yang paling banyak dijumpai dalam lingkungan sehari-hari atau dalam industri (Ha Ming Ang dkk,2006).

Model aliran yang lazim dijumpai ada dua macam aliran yaitu laminer dan turbulen. Untuk hal ini peneliti membatasi masalah untuk meneliti dengan model aliran laminer.

Temperatur sistem dimana terjadi proses pengerakan bisa sangat bervariasi. Dalam hal ini peneliti melakukan pembatasan temperatur dengan memilih temperatur kamar dengan alasan bahwa pada temperatur tersebut proses pengerakan terjadi secara alami.

Aditif yang akan digunakan untuk menghambat pertumbuhan kerak adalah ion $\mathrm{Cu}^{2+}$. Pemilihan aditif ini berdasarkan pemikiran bahwa ion $\mathrm{Cu}^{2+}$ ( tembaga ) adalah jenis ion yang lazim dijumpai sebagai impuritas dalam air terbuka, air sumber maupun pada sistem industri. Kecepatan aliran yang dipilih mempunyai tiga variasi kecepatan volumetrik yaitu $30 \mathrm{~mL}, 40 \mathrm{~mL}$ dan 50 $\mathrm{mL}$ per menit.

\section{TINJAUAN PUSTAKA}

Pengerakan dalam pipa adalah suatu proses terbentuknya endapan yang terjadi dalam kondisi alami pada suatu pipa yang mengalirkan air dengan kesadahan, temperatur, kecepatan dan konsentrasi yang tertentu(Ha Ming Ang,2007). Pengerakan dipengaruhi oleh kondisi phisik, seperti temperatur, kecepatan aliran, model aliran serta dipengaruhi pula oleh kondisi kimia seperti tingkat kesadahan air yang mengalir dalam pipa, intensitas impuritas yang berada dalam air. Bisa dikatakan disini bahwa kondisi air yang dialirkan itulah yang pada akhirnya menimbulkan permasalahan kerak itu sendiri( $\mathrm{Al}$ Barrak dan Rowell,2006).

Kemungkinan bahwa air akan mengendapkan kerak bisa diukur dengan water analysis. Ukuran dari water hardness ( kesadahan ), $\mathrm{pH}$ dan rasio klorid dengan carbonat adalah merupakan indikator adanya kemungkinan bahwa air akan menimbulkan endapan kerak(Managing Queenslands Natural Resources,2006). Pembentukan kerak juga dipengaruhi oleh beberapa perubahan yang terjadi di dalam air termasuk di dalamnya perubahan sifat phisik maupun perubahan sifat kimia dalam system pengaliran air. Sebagai contoh pelepasan karbon dioksida pada waktu proses pemompaan dari sumur akan memacu terjadinya reaksi kimia yang akan mengakibatkan timbulnya kerak(Managing Queenslands Resources,2006). Kenaikan temperatur, perubahan kecepatan dan tekanan, perubahan $\mathrm{pH}$ juga akan memicu timbulnya kerak( Ha Ming Ang dkk,2007). Kesadahan air yang tinggi yaitu ditandai dengan tingginya kandungan ion $\mathrm{Ca}^{2+}$, ion $\mathrm{Mg}^{2+}$, ion $\mathrm{Cl}^{-}$, ion $\mathrm{SO}_{4}{ }^{2-}$ dan ion $\mathrm{HCO}_{3}{ }^{-}$sangat memicu proses terjadinya kerak. Ion-ion yang disebutkan akan mengalami reaksi sebagai berikut (Azimi dan Papangelakis,2009):

$$
\begin{array}{llll}
\mathrm{Ca}^{2+}+\mathrm{Cl}_{2}{ }^{-} & \leftrightarrow & \mathrm{CaCl}_{2} \\
\mathrm{Ca}^{2+}+\mathrm{SO}_{4}{ }^{2-} & \leftrightarrow & \mathrm{CaSO}_{4} \\
\mathrm{Mg}^{2+}+\mathrm{Cl}^{2-} & \leftrightarrow & \mathrm{MgCl}_{2} \\
\mathrm{Mg}^{2+}+\mathrm{SO}_{4}{ }^{2-} & \leftrightarrow & \mathrm{MgSO}_{4}
\end{array}
$$

Kerak biasanya merupakan senyawa mineral yang berupa kalsium karbonat, kalsium sulfat, magnesium karbonat dan dalam keadaan tertentu disertai pula unsur-unsur lain yaitu mineral besi serta butiran pasir, namun demikian kerak kalsium sulfatlah $\left(\mathrm{CaSO}_{4}\right)$ yang paling banyak dijumpai dan lazim dinamakan orang sebagai kerak gypsum.

\section{METODOLOGI}

Bahan yang akan digunakan dalam penelitian ini meliputi : Kristal $\mathrm{CaCl}_{2} \cdot 2 \mathrm{H}_{2} \mathrm{O}$ (Calsium Clorid Dehidrad) ; kristal $\mathrm{Na}_{2} \mathrm{SO}_{4}$ (NatriumSulfat); $\mathrm{H}_{2} \mathrm{O}$ (aquades) dan kristal $\mathrm{CuCl}_{2}$ (Cuprum Clorid) dimana semuanya grade analitik.

Peralatan yang digunakan meliputi : pompa air, daya 20 watt, jumlah 2 buah, kapasitas 10 L/jam ; gelas ukur dan stopwatch, untuk mengukur kecepatan aliran air ; TDS, untuk mengukur konduktifitas listrik pada larutan ; stabiliser tegangan listrik ; bejana penampung larutan kapasitas 10 liter 3 buah ; coupon ( tabung pengerakan).

Disain alat yang dimaksudkan seperti terlihat pada Gambar 1. Alat tersebut memiliki lima bejana penampung larutan yaitu bejana I dan III untuk menampung larutan $\mathrm{CaCl}_{2}$ ,bejana IIIdan IV menampung larutan $\mathrm{Na}_{2} \mathrm{SO}_{4}$ sedangkan bejana $\mathrm{V}$ digunakan untuk menampung limbah. Pompa 1 yang dipasangkan digunakan memompa larutan dari bejana I menuju bejana III, pompa 2 digunakan untuk memompa larutan dari bejana II menuju bejana IV. Permukaan larutan pada bejana III serta bejana IV dijaga agar keduanya mempunyai ketinggian yang sama yaitu dengan cara memasangkan saluran yang terbuka dari bejana III menuju bejana I dan dari bejana IV menuju bejana II. Pada skema terlihat notasi $\Delta \mathrm{h}$ yaitu merupakan selisih ketinggian antara permukaan bejana III dan IV terhadap ketinggian saluran limbah. $\Delta \mathrm{h}$ bisa diatur dengan maksud untuk mendapatkan laju alir yang berbeda-beda sesuai dengan yang direncanakan yaitu sebesar 30 $\mathrm{mL} /$ menit; $40 \mathrm{~mL}$ per menit dan $50 \mathrm{~mL}$ / menit. Nilai $\Delta \mathrm{h}$ didapat melalui langkah trial and error. Larutan yang terdapat pada bejana III dan IV 
secara bersamaan dialirkan menuju coupon dan seterusnya menuju penampungan limbah. Pada coupon ion $\mathrm{Ca}^{+}$dan ion $\mathrm{SO}_{4}^{-}$dari kedua larutan mengadakan reaksi dan mengendap pada dinding coupon sehingga terjadi kerak $\mathrm{CaSO}_{4}$. Nilai konduktivitas yang berubah pada saluran limbah diukur dengan menggunakan TDS (Total Disolve Solid ) yaitu suatu instrumen yang bisa digunakan untuk mengukur konduktivitas larutan. Pengukuran konduktifitas larutan dilakukan setiap lima menit sekali.

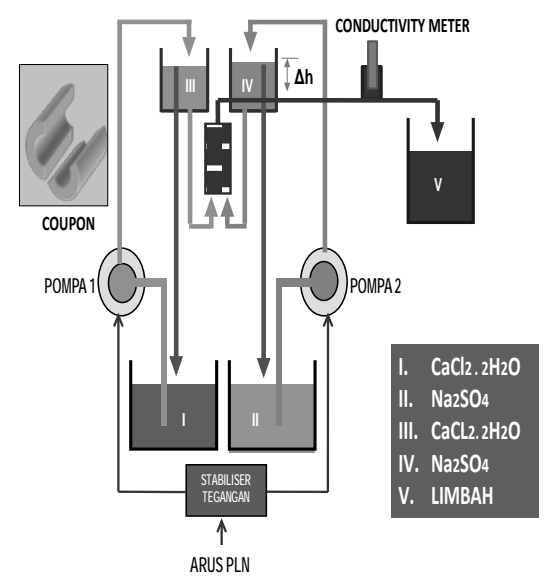

\section{Gambar 1. Skema Alat Percobaan Pembuatan Kerak Gypsum}

Perhitungan dan pembuatan larutan $\mathrm{CaCl}_{2} \cdot 2 \mathrm{H}_{2} \mathrm{O} ; \quad \mathrm{Na}_{2} \mathrm{SO}$ dan $\mathrm{CuCl}_{2}$ dilakukan sbb : konsentrasi Ca sebesar 3500 ppm adalah setara dengan 3,5 gram/liter. Karena $\mathrm{BA} \mathrm{Ca}=40$ sedangkan $\mathrm{BM} \mathrm{CaCl}_{2} \cdot 2 \mathrm{H}_{2} \mathrm{O}$ adalah 147 maka bisa ditemukan berat $\mathrm{CaCl}_{2} \cdot 2 \mathrm{H}_{2} \mathrm{O}$ yaitu $3,5 / 40$ x 147 $=12,8625$ gram/liter. Sedangkan perhitungan berat $\mathrm{SO}_{4}$ dihitung dengan cara mengacu pada senyawa $\mathrm{CaSO}_{4}$ dimana mempunyai BM 136 sedangkan $\mathrm{SO}_{4}$ mempunyai BM 96, maka berat $\mathrm{CaSO}_{4}$ menjadi $3,5 / 40$ x $136=11,9$ gram/liter. Selanjutnya $\mathrm{SO}_{4}$ bisa didapatkan yaitu 11,9/136 x $96=8,4$ gram/liter. Seperti diketahui bahwa $\mathrm{SO}_{4}$ berada dalam senyawa $\mathrm{Na}_{2} \mathrm{SO}_{4}$ dengan $\mathrm{BM}=142$. Maka kebutuhan $\mathrm{Na}_{2} \mathrm{SO}_{4}$ per liter adalah 8,4/96 x 142= 12,425 gram/liter. Kebutuhan $\mathrm{CuCl}_{2}$ konsentrasi 5 ppm bisa dihitung sbb : 0,005/63,55 x 127,55 $=0,01$ gram/liter sedangkan untuk konsentrasi10 ppm: 0,01/63,55 x 127,55 = 0,02 gram /liter.

Setelah jumlah kebutuhan senyawa kalsium dan senyawa sulfat telah dihitung dengan baik maka mulailah langkah pembuatan larutan. Yang perlu dipersiapkan adalah aquades ; kertas membran; bejana dari plastik; gelas ukur; gelas labu; timbangan analitik; pengaduk dari plastik. Langkah berikutnya adalah melakukan penimbangan kebutuhan $\mathrm{CaCl}_{2} \cdot 2 \mathrm{H}_{2} \mathrm{O}$ dan $\mathrm{Na}_{2} \mathrm{SO}_{4}$ sesuai dengan hasil perhitungan. Kemudian bejana diisi dengan aquades sebanyak satu liter dan $\mathrm{CaCl}_{2} \cdot 2 \mathrm{H}_{2} \mathrm{O}$ dimasukkan dengan diaduk sampai rata. Selanjutnya ditambah dengan aquades lagi hingga volumenya mencapai lima liter. Untuk menghilangkan partikel yang terbawa dalam larutan dilakukan penyaringan menggunakan kertas penyaring. Dengan demikian maka larutan $\mathrm{CaCl}_{2} \cdot 2 \mathrm{H}_{2} \mathrm{O}$ telah siap. Langkah ini juga dilakukan pula untuk pembuatan larutan $\mathrm{Na}_{2} \mathrm{SO}_{4}$ mulai dari volume lima hingga tujuh liter.

Jumlah coupon ada empat dipasang dari bawah keatas seperti telah terlihat pada gambar sebelumnya. Dimensi coupon adalah; panjang 30 $\mathrm{m}$; diameter luar $18 \mathrm{~mm}$ dan diameter dalam 12,5 $\mathrm{mm}$. Sebelum dipasangkan pada rumahnya terlebih dahulu coupon dipoles hingga permukaan bagian dalam menjadi halus. Selanjutnya n dalam menjadi halus. Selanjutnya dicelupkan di dalam cairan $\mathrm{HCl}$ selama 3 menit terus dibilas dengan air bersih dan yang terakhir dibilas dengan aquades. Setelah itu dikeringkan dengan memakai hair dryer. Selanjutnya coupon dipasang pada rumah coupon.

Pengambilan data (percobaan) dilakukan sebanyak sembilan kali yaitu terdiri dari tiga kali percobaan untuk pembentukan kerak tanpa aditif, enam kali percobaan untuk pembentukan kerak dengan aditif ion $\mathrm{Cu}^{2+}$. Pertama kali larutan $\mathrm{CaCl}_{2} \cdot 2 \mathrm{H}_{2} \mathrm{O}$ dimasukkan sejumlah lima liter dalam bejana I selanjutnya larutan $\mathrm{Na}_{2} \mathrm{SO}_{4}$ dimasukkan kedalam bejana II lima liter pula. Setelah itu pompa dihidupkan dan larutan akan naik mengisi sampai batas atas bejana III dan bejana IV dan segera kemudian pompa dimatikan. Beberapa saat kemudian pompa dihidupkan dan larutan mulai mengisi coupon dan dengan demikian runing telah dimulai. Pencatat waktu pada saat yang sama juga diaktifkan dimana setiap dua menit sekali perlu dilakukan pengukuran terhadap konduktifitas larutan. Untuk melakukan pengukuran konduktifitas larutan limbah larutan yang keluar dari coupon ditampung pada bejana kecil yang terbuat dari plastik dan segera mungkin elektroda TDS dimasukkan. TDS akan mengukur nilai konduktifitas larutansehingga pembacaan digitalnya mulai berjalan dari nol naik terus sehingga akhirnya berhenti. Angka yang terakhir inilah yang dicatat. Demikian ini dilakukan berulang ulang setiap lima menit sekali. Setelah waktu mencapai empat jam maka pompa dihentikan dan saluran menuju coupon dilepas. Satu jam kemudian coupon diambil dari rumahnya dan dikeringkan dalam oven suhu $60^{\circ} \mathrm{C}$ selama enam jam.

\section{HASIL DAN PEMBAHASAN}

Pembahasan kajian kinetis yang dilakukan meliputi kajian waktu induksi (laju reaksi) yaitu waktu yang dibutuhkan oleh senyawa kalsium sulfat untuk membentuk inti kristal pertamakali. 
Waktu ini ditandai dengan menurunnya konduktifitas larutan dimana menandakan bahwa ion-kalsium telah bereaksi dengan ion sulfat dan mengendap membentuk inti kerak. Waktu induksi untuk laju alir $30 \mathrm{~mL} / \mathrm{menit,} 40 \mathrm{~mL} / \mathrm{menit}$ dan 50 $\mathrm{mL} /$ menit masing-masing menunjukkan angka yang berbeda. Hal ini bisa dibaca melalui grafik Hubungan Antara Konduktifitas Dengan Waktu yang dicantumkan pada Gambar 2.

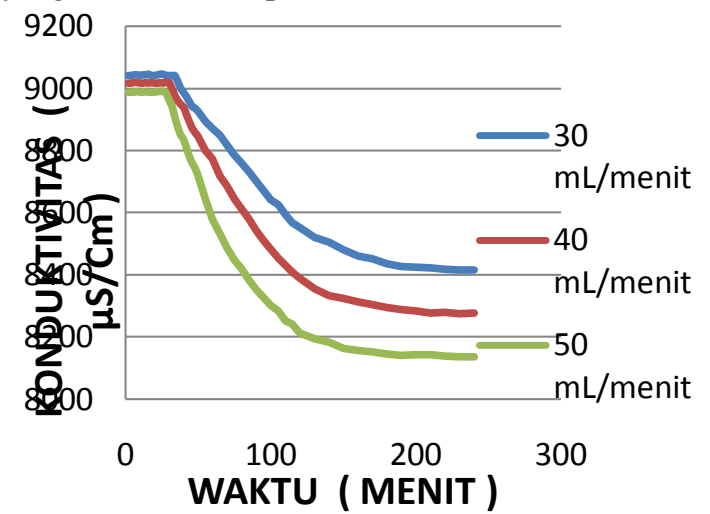

Gambar 2. Grafik hubungan antara konduktivitas dengan waktu, tanpa aditif

Pada grafik diatas terlihat bahwa waktu induksi untuk laju alir $30 \mathrm{~mL} / \mathrm{menit}$ adalah lebih besar yaitu 34 menit. Sedangkan untuk laju alir 40 $\mathrm{mL} /$ menit waktu induksi sebesar 30 menit dan dan untuk laju alir $50 \mathrm{~mL} /$ menit waktu induksi sebesar 26 menit. Hal ini bisa digunakan sebagai dasar dalam mengambil kesimpulan bahwa didalam proses pertumbuhan kerak gypsum laju alir mempunyai pengaruh terhadap waktu terbentuknya inti kristal pertamakali. Bentuk pengaruhnya adalah semakin tinggi laju alir maka waktu pembentukan inti kristal akan semakin pendek. Implikasi lebih lanjut dari kesimpulan ini adalah bila inti kristal lebih cepat terbentuk maka massa kristal akan menjadi lebih banyak.

Distribusi nilai konduktifitas seperti terlihat pada Gambar 2 ternyata menunjukkan kondisi yang tidak terduga sebelumnya. Konduktifitas yang tercatat lima menit pertama untuk tiga variasi laju alir menunjukkan angka yang berbeda yaitu 9041 $\mu \mathrm{S} / \mathrm{Cm}, 9016 \mu \mathrm{S} / \mathrm{Cm}$ dan $8988 \mu \mathrm{S} / \mathrm{Cm}$ dari laju alir terrendah ke tertinggi. Pada menit ke 200 dimana konduktifitas larutan mulai stabil nilainyapun berbeda pula untuk ketiga variasi laju alir yaitu sebesar $8430 \mu \mathrm{S} / \mathrm{Cm}, 8275 \mu \mathrm{S} / \mathrm{Cm}$ dan 8135 $\mu \mathrm{S} / \mathrm{Cm}$. Hal ini bisa disimpulkan sebagai berikut : mengingat bahwa kerak terbentuk oleh adanya reaksi dan pengendapan antara ion-ion maka bila semakin banyak ion yang bereaksi dan mengendap akan menjadikan konduktifitas larutan menjadi lebih kecil. Akibat lebih lanjut adalah akan terbentuk massa kerak yang lebih banyak.

Setelah larutan diberi ion $\mathrm{Cu}^{2+}$ sebanyak lima ppm dan kemudian dilakukan percobaan maka didapatlah waktu induksi pembentukan kristal gipsum. Grafiknya dicantumkan dalam Gambar 3. Pada gambar yang dimaksudkan bisa didapatkan bahwa waktu induksi mempunyai nilai sebesar 30 menit untuk laju alir $50 \mathrm{~mL} /$ menit, 34 menit untuk laju alir $40 \mathrm{~mL} / \mathrm{menit}$ dan 38 menit untuk laju alir $30 \mathrm{~mL} / \mathrm{menit}$. Nilai konduktifitas larutan yang dicatat mempunyai nilai 9072 - $8470 \mu \mathrm{S} / \mathrm{Cm}$ untuk laju alir $30 \mathrm{~mL} / \mathrm{menit}$; 9047 - $8321 \mu \mathrm{S} / \mathrm{Cm}$ dan 9016 - $8182 \mu \mathrm{S} / \mathrm{Cm}$. Data ini bisa memberikan informasi bahwa penambahan aditif sebesar lima ppm menjadikan waktu induksi lebih panjang dibanding tanpa aditif. Akibat lebih lanjut tentu saja massa kerak juga akan lebih berkurang.

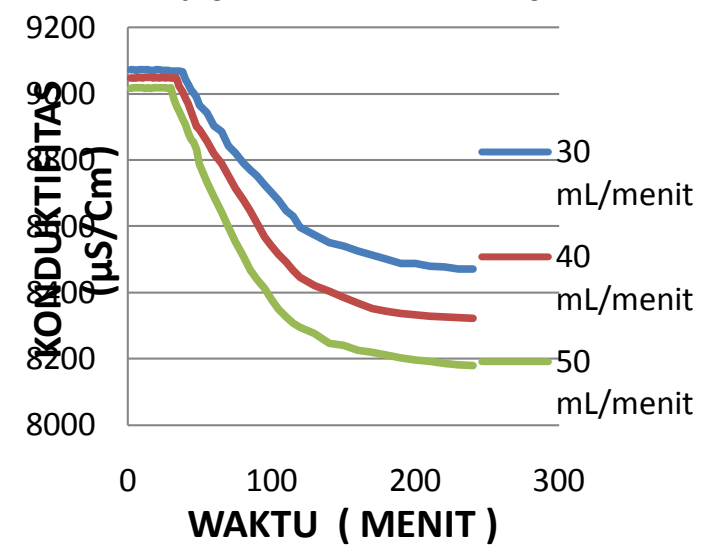

Gambar 3. Grafik hubungan konduktifitas dengan waktu dengan aditif 5 ppm

Pada kajian ini aditif ion $\mathrm{Cu}^{2+}$ dinaikkan lagi konsentrasinya menjadi sebesar 10 ppm. Percobaan yang dilakukan melalui prosedur yang sama dengan sebelumnya dan hasilnya diuraikan berikut ini. Waktu induksi pembentukan kristal gipsum mengalami peningkatan yaitu 34 menit untuk laju alir $50 \mathrm{~mL} /$ menit, 38 menit untuk laju alir 40 $\mathrm{mL} / \mathrm{menit}$ dan 42 menit untuk laju alir 30mL/menit, seperti yang dicantumkan pada Gambar 3. Adapun hasil pencatatan konduktifitas larutan setiap dua menit bisa dibaca pada grafik yang telah dicantumkan. Konduktifitas mulai percobaan dan setelah akhir percobaan yaitu pada menit ke 240 didapatkan sbb : 9102 - $8528 \mu \mathrm{S} / \mathrm{Cm}$ untuk laju alir $30 \mathrm{~mL} / \mathrm{menit}, 9075$ - $8401 \mu \mathrm{S} / \mathrm{Cm}$ untuk laju alir $40 \mathrm{~mL} / \mathrm{menit}$ dan 9043 - $8291 \mu \mathrm{S} / \mathrm{Cm}$ untuk laju alir 50mL/menit. Angka-angka ini sedikit mengalami penurunan dibanding dengan data yang dicatat pada penambahan aditif sebesar lima ppm.

Lebih lanjut kajian kinetis ini bisa diperjelas melalui pembuatan grafik yang menunjukkan hubungan antara waktu induksi dengan laju alir seperti tercantum dalam Gambar 4. Melalui grafik tersebut terbaca dengan jelas nilai waktu induksi untuk tiga variasi laju alir tanpa aditif, dengan aditif lima ppm dan dengan aditif 10 ppm. Berturut-turut nilai waktu induksi untuk tanpa aditif, dengan aditif lima ppm dan dengan aditif 10 ppm adalah 34; 38 dan 42 menit untuk laju alir $30 \mathrm{~mL} /$ menit, 30; 34 dan 38 menit untuk laju alir $40 \mathrm{~mL} /$ menit dan 24; 28 dan 32 menit untuk laju alir 50 mL/menit. 
Dengan demikian bisa disimpulkan bahwa laju alir yang lebih tinggi baik tanpa aditif maupun dengan aditif dalam proses kristalisasi gipsum menyebabkan lebih mudah pembentukan kristal dibanding dengan laju alir yang lebih rendah. Pembentukan kristal yang lebih cepat akan menyebabkan lebih mudah pula terjadi proses pengerakan.

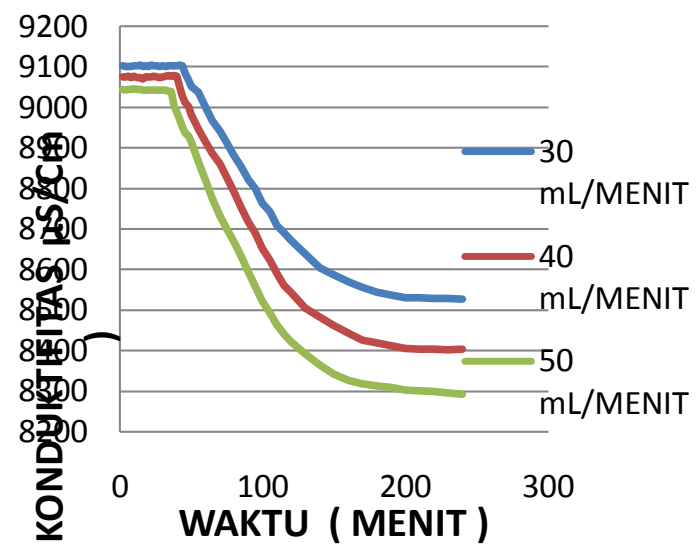

Gambar 4. Grafik hubungan konduktifitas dengan waktu, aditif $10 \mathrm{ppm}$

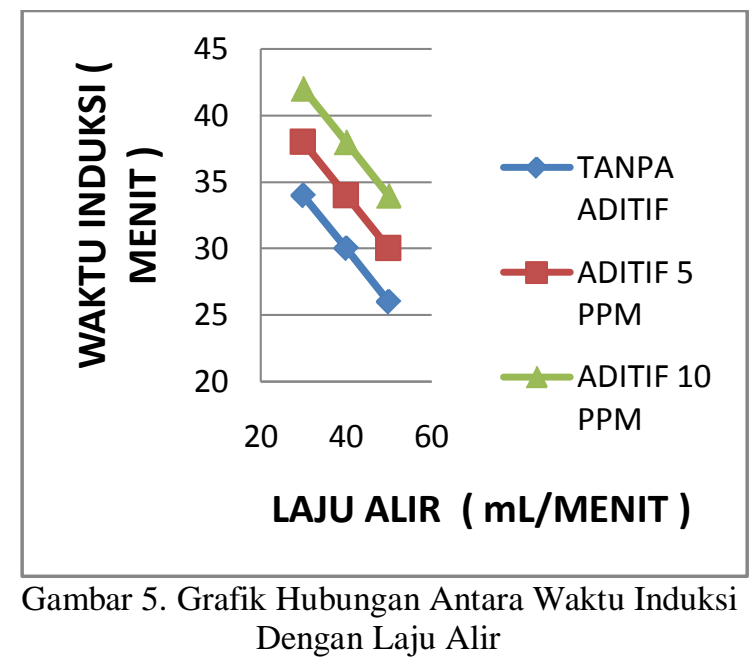

\section{KESIMPULAN}

Waktu induksi untuk percobaan tanpa menggunakan aditif berturut-turut dari laju alir 30; 40 dan 50 mL/menit adalah 34; 30 dan 26 menit. Hal ini memberikan arti bahwa semakin besar laju alir maka waktu pembentukan kristal akan semakin cepat dan pertumbuhan kerak akan semakin lebih cepat pula.

Penambahan aditif ion $\mathrm{Cu}^{2+}$ sebesar $10 \mathrm{ppm}$ mengakibatkan waktu induksi meningkat. Sebagai contoh pada laju alir $50 \mathrm{~mL} /$ menit waktu induksi meningkat dari 26 menjadi 34 menit. Jadi pembentukan kristal yang semula membutuhkan waktu 26 menit berubah menjadi 34 menit. Maka bisa disimpulkan bahwa aditif ion $\mathrm{Cu}^{2+}$ yang ditambahkan mampu menghambat pertumbuhan kerak.
Bagi operator industri dimana dalam sistem industrinya menggunakan air yang mengalir disarankan untuk memilih laju alir serendah mungkin sepanjang masih memenuhi ketentuan industri untuk mencegah atau menghambat pertumbuhan kerak gipsum. Sebagai contoh bila laju alir yang diijinkan dalam panduan operasi adalah 2 - 4 m per detik maka sebaiknya memilih yang terrendah yaitu $2 \mathrm{~m}$ per detik.

Bagi disainer atau perancang industri agar memilih penampang pipa yang lebih besar untuk mengalirkan air sehingga untuk debit yang sama laju alirnya bisa menjadi lebih rendah dan diharapkan bisa menghambat pertumbuhan kerak gipsum.

\section{DAFTAR PUSTAKA.}

1. Ang. Haming, et all, 2006, Gypsum scale Formation Control In Pipe Flow System : A Systemic Study On The Effect Of Process Parameters An Additives, Curtin University Of Technology, Perth,Australia.

2. Al-Barrak.K, Rowell. D.L, 2006, The Solubility Of Gypsum In Calcareous Soil, Science Direct, 136 pp : 830-837.

3. Beck. Ralf, et all, 2009, The Effect Of Crystalization Conditions, Cristal Morphology And Size On Pressure Filtration Of L-Glutamic Acid And An Aromatic Amine, Elseiver, Separation And Publication Technology, 66 pp:549-558.

4. Hoang. Tung A, et all, 2007, Effect Temperature On Scaling Of Calcium Sulfate In Pipe, Powder Technology 179 pp: 31-37.

5. Isopescu.Raluca, et all, 2009, The Effect Of Organic Additive On Induction Time And Characteristic Of Precipitated Calcium Carbonate, Chemical Engineering And Research Design.

6. Jamaialahmadi. M, Steinhagen. H. Muller, 2007, Heat Exchanger Fouling And Cleaning In The Dehydrate Process For The Production Of The Phosporic Acid, Chemical Engineering Research And Design, 85 pp : 245-255.

7. Jun. Liu Wen, et all, 2009, Anti Scaling Properties Of Zinc Ion And Copper Ion In The Recycling Water, Ionics, 15 pp: 337-343.

8. Mwaba. Misheck G, et all, 2007, Effect Of Magnetic Field On Calcium Sulfate Crystal Morphology, Journal Of Crystal Growth, 303 pp : 381-386.

9. Mwaba. M. G, et all, 2006, A Semi Emperical Correlation For Crystalization Fouling On Heat Exchange Surfaces, Applied Thermal Engineering, 26 pp: 440447. 
10. Sayan. Pervis, et all, 2007, Effect Of Trace Metals On Reactive Crystalization
Gypsum, Cryst. Res. Technol. 42 pp: 961970.

Tabel 1. Kebutuhan $\mathrm{CaCl}_{2} \cdot 2 \mathrm{H}_{2} \mathrm{O} ; \mathrm{Na}_{2} \mathrm{SO}_{4}$ dan $\mathrm{CuCl}_{2}$

\begin{tabular}{cccccc}
\hline $\begin{array}{c}\text { Lajur Alir } \\
\text { (mL/menit) }\end{array}$ & $\begin{array}{c}\text { Volume } \\
\text { (liter) }\end{array}$ & $\begin{array}{c}\text { CaCl2.2H20 } \\
\text { (gram) }\end{array}$ & $\begin{array}{c}\text { Na2SO4 } \\
\text { (gram) }\end{array}$ & $\begin{array}{c}\text { CuCl2 5ppm } \\
\text { (gram) }\end{array}$ & $\begin{array}{c}\text { CuCl2 10ppm } \\
\text { (gram) }\end{array}$ \\
\hline 30 & 10 & 128,6250 & 124,2500 & 0,1 & 0,2 \\
40 & 12 & 154,3500 & 149,1000 & 0,12 & 0,24 \\
50 & 14 & 180,0750 & 173,9500 & 0,14 & 0,28 \\
\hline
\end{tabular}

